JAAR

19,1

2

Received 10 February 2015

Revised 25 September 2015

26 May 2016

31 October 2016

5 January 2017

2 February 2017

Accepted 12 February 2017

\section{Earnings quality across different reporting regimes \\ Listed, large private, medium-sized, small and micro companies in the UK}

\author{
Siming Liu \\ Department of Economics and Finance, Brunel University, Uxbridge, UK, and \\ Len Skerratt \\ Brunel Business School, Brunel University, Uxbridge, UK
}

\begin{abstract}
Purpose - Since the UK Companies Act 1981, different reporting standards have developed for different classes of company to reduce the reporting burden on non-listed companies. There are now different regimes for listed, large private, medium-sized, small and micro companies. This strategy raises the issue of whether earnings quality across the different classes of company is comparable. The paper aims to discuss this issue. Design/methodology/approach - The paper uses the smoothness of earnings to measure reporting quality across the different types of companies from 2006 to 2013, based on 514,000 observations. Smoothness is an indicator of poor quality.

Findings - The authors find that listed companies have the highest earnings quality, closely followed by small and micro companies. In contrast, large private and medium-sized companies have much lower earnings quality. Overall, the authors find companies which switch between reporting regimes have lower earnings quality. The authors also find that earnings quality is not affected by the small company exemption from audit.

Research limitations/implications - Companies filing abbreviated accounts are excluded since they do not file an income statement. The recent revisions to UK GAAP (FRS 102 and FRS 105) are not examined due to insufficient data.

Practical implications - The Financial Reporting Council's (FRC) strategy of reducing the financial reporting and auditing obligations for small companies seems not to have significantly affected earnings quality. However, the FRC may need to review the reporting requirements of large private and medium-sized companies and also the option of companies to switch between reporting regimes; in these settings earnings quality appears to be weaker.

Originality/value - The paper studies the effect of earnings quality across the different reporting regimes in the UK. Novel and important features of the study are that the sample covers a wide variety of small and micro companies which have not been analyzed previously; the results are disaggregated by year, for assurance that the results are not driven by a single rogue year; and the authors also address the small company exemption from audit, and the flexibility of non-listed companies to switch between regimes.
\end{abstract}

Keywords Audit, Earnings quality, Comparability, Switching, Reporting regimes,

SMEs and micro companies

Paper type Research paper

\section{Introduction}

One of the key developments in UK financial reporting since the early 1980s has been the exemption of certain companies from the full reporting requirements applicable to listed companies. Starting in 1981 with the option for small- and medium-sized companies to file abbreviated accounts with the Registrar of Companies, followed by small companies being exempt from audit, there is now a structure in which there is a different set of

\footnotetext{
(C) Siming Liu and Len Skerratt. Published by Emerald Publishing Limited. This article is published under the Creative Commons Attribution (CC BY 4.0) licence. Anyone may reproduce, distribute, translate and create derivative works of this article (for both commercial and non-commercial purposes), subject to full attribution to the original publication and authors. The full terms of this licence may be seen at http://creativecommons.org/licences/by/4.0/legalcode
}

Journal of Applied Accounting Research

Vol. 19 No. 1, 2018 pp. $2-19$

Emerald Publishing Limited 0967-5426

DOI 10.1108/JAAR-02-2015-0009 
accounting standards for each of the following classes of company: listed; large private and medium-sized; small; and, finally (as a result of EU Directive 2012/6), micro companies. But what are the consequences of this multi-tier structure of reporting?

Much of the discussion has been about reducing the cost burden on companies, but little has been said about the effect on the quality of reporting. This issue is well captured by Nigel Sleigh-Johnson, the Head of ICAEW's Financial Reporting Faculty, who said:

Only time will tell whether the reduction in the information required in small company accounts is a

sensible reduction in Red Tape or a source of risk to the UK economy (ICAEW, 2015).

One possible intention of the multi-tier approach may have been to maintain comparability across the groups whilst reducing reporting costs for smaller companies. In this case, large companies with more complex operations and more serious agency problems would be subject to comprehensive standards, whilst smaller companies with relatively simple operations (and therefore with little opportunity for earnings management) would need less stringent rules. In contrast, another potential objective may have been that the quality of reporting should reflect the varying needs of users. In this case, smaller companies would be less regulated since users' requirements are relatively modest, and it may be easier to obtain information outside of the cycle of the annual report and accounts. In this setting, one would expect the quality of the reporting to be superior for larger companies.

It is important to ascertain the consequences of the relaxation of rules for private companies since comparability is an important feature of the financial statements of companies (IASB, 2009, para. BC36; FRC, 2015, para. 2.11; Kim et al., 2016). Indeed, it was the basis of the dissension by James Leisenring from the International Accounting Standards Board's standard for small- and medium-sized entities (IASB, 2009, para. DO3). Prior work on the differences between different classes of company in the UK is limited. The studies do not examine very small (micro) companies, which constitute the vast majority. Furthermore, they examine data of more than ten years ago and, therefore, do not reflect the current environment in which exemptions for different classes of company are substantial.

We extend this prior work significantly. The first contribution is to compare earnings quality from 2006 to 2013 for the different classes of company: listed companies that reported under International Financial Reporting Standards (IFRS); large private and medium-sized companies that reported under UK GAAP (FRSs, SSAPs and UITFs); and small and micro companies that reported under the Financial Reporting Standard for Smaller Entities (FRSSE). Although these regimes have now been replaced by IFRS, FRS 102 and FRS 105, it will be some time before a large data set is available based on the new standards. An important feature is to analyse micro companies which are a key focus of the EU Directive 2013/34; these companies constitute over 40 per cent of our large scale sample of 514,000 company-year observations. We also provide annual disaggregation so as to identify the permanence of any differences between company groups. A key finding is that listed companies have the highest earnings quality, closely followed by small and micro companies; large private and medium-sized companies have the poorest earnings quality. The result for listed companies is not surprising since they are required to follow IFRS. Also, small and micro companies are likely to have relatively straightforward transactions, with little opportunity for significant earnings management. In contrast, large private and medium-sized companies are neither required to follow IFRS and may have transactions for which there is more discretion under UK GAAP.

We also explore other key aspects of the multi-tier reporting regime. One feature is that nonlisted companies are permitted to switch to a reporting regime designed for larger companies and also to switch back to the regime intended for the companies (the home regime). For example, small companies were intended to report under FRSSE, but were permitted to use UK GAAP or IFRS. The new reporting structure of IFRS, FRS 102 and FRS 105 
JAAR

19,1

maintains this flexibility. Our second contribution is to examine the effect of this regime switching. Although switching to a regime intended for a larger company would not seem to be controversial since the rules are likely to be tighter, switching in either direction may give rise to comparability issues, both over time and across companies. Furthermore, there is no study which focusses on this little discussed aspect of the regulation in the UK. Overall, we find that companies which switch between reporting regimes have lower earnings quality than those which remain in the home regime.

Another characteristic of the multi-tier reporting regime is that small and micro companies are exempt from audit. Our third contribution is to assess the effect of this option. We compare the earnings quality of the companies which exercised this option with those companies which did not. In contrast to prior research, our sample is large and covers the full range of small and micro companies for the years 2006-2013, with annual disaggregation. We find that, with the exception of 2013, the exemption of small and micro companies from audit does not reduce earnings quality.

The structure of the paper is as follows. Section 2 outlines the regulatory framework of the UK multi-tier reporting system. This is followed by a review of the prior literature on the impact of such a system, thus identifying the issues to be addressed in this study. Section 4 discusses the research method and data which we use. Then follows a discussion of the results in Section 5, and we conclude with a summary in Section 6.

\section{The development of the multi-tier regime}

One of the major developments in UK financial reporting over the last few years has been the emergence of different reporting regimes for different classes of company. It was the Companies Act 1981 that first defined small- and medium-sized companies and permitted them to file-modified accounts (subsequently called abbreviated accounts by the Companies Act 1985) with the Registrar of Companies. Another significant change came in 1994, when small companies were not required to have an audit. A further relaxation of the reporting regulations for small companies came about in 1997 when they were allowed to adopt simpler accounting rules under the FRSSE, for both reporting to shareholders and the Registrar of Companies (Chopping and Skerratt, 1997). However, they were also permitted to report under regular UK GAAP if they chose.

At the other end of the company spectrum, in 2005, the EU required listed companies to follow IFRS, thus leaving unlisted medium-sized and large companies to be covered by a mix of the UK's Financial Reporting Standards (FRS), the earlier issued Statements of Standard Accounting Practice (SSAP) and the recommendations of the Urgent Issues Task force (UITF)[1]. In order to rationalise the reporting rules for these companies which were neither small nor listed, the Accounting Standards Board[2] took advantage of the International Accounting Standards Board's development, in 2009, of its International Accounting Standard for small- and medium-sized entities (IFRS for SME) and used it as a base for the development of FRS 102 issued in 2013 to regulate the financial reporting of medium-sized unlisted entities.

The next important development emanated from EU Directive 2012/6 (European Union, 2012) which gave exemptions from fourth and seventh directives to a new class of company, the micro company. In response to this, the FRSSE was amended in April 2014. Shortly after this came EU Directive 2013/34 (European Union, 2013) which combined and amended the existing fourth and seventh directives with the intention of reducing disproportionate costs imposed on small companies. The changes were so substantial that, in response, the Financial Reporting Council (FRC) withdrew the FRSSE, locating the reporting regulations for micro companies within a new standard (FRS 105) and the regulations for small companies in a special section of a revised FRS 102. The FRC maintained the option of non-listed companies to report under a regime intended for larger companies, and then to 
switch back to the home regime if desired. In addition, as allowed under the EU Accounting Directive, the FRC increased the thresholds for small and medium companies.

Accounting standards are a significant determinant of earnings quality (Soderstrom and Sun, 2007). Therefore, an important question that arises is whether accounting statements will be comparable across the different regimes? One rationale for a multi-tier system is that agency issues and complexity vary across the tiers, the objective of regulation being the equalisation of earnings quality across the classes of company. Other justifications may give rise to differences in earnings quality. For example, users' needs may be different; large companies typically have complex business operations, suggesting that disclosures need to be comprehensive, especially when stakeholders may find it difficult to obtain information outside of the cycle of the annual report and accounts. This situation contrasts with smaller companies which are likely to be less complex and provide information to stakeholders in a less formal way. In Section 3, we discuss the prior empirical research which may have some bearing on the likely effects of the multi-tier regime in the UK. This identifies the gaps in the literature and leads to the research questions which we address in this study.

\section{Prior literature and research questions}

\subsection{The effect of equity market discipline on earnings quality}

Much of the prior literature about earnings quality across different types of company is concerned with the discipline exerted by equity markets in stifling opportunistic reporting. However, listing status is only one of the factors which separate UK reporting regimes; the size of a company also matters. Therefore, the insights to be gained from this literature are limited, since the studies do not distinguish between different sizes of private company. Furthermore, in attempting to identify the impact of market discipline, they restrict their sample to where companies operate under the same reporting regime.

There are three main studies in this category. Beatty et al. (2002) find that during the period 1988-1998, US public banks have superior earnings quality to private banks. However, since the study relates only to the banking sector, the findings may not have implications for the current study. Ball and Shivakumar (2005) is the only UK study of differential reporting, investigating the public/private dichotomy for companies facing the same auditing and reporting requirements during the period 1989-1999. They find that public companies have a higher earnings quality than private companies. This may suggest that private companies will also have lower earnings quality when they are under a less restrictive reporting regime. However, the results have limited implications for the issues here since the measure of quality used is loss recognition, which is only one aspect of earnings quality, and the sample is now very dated. Furthermore, although the number of observations of 115,000 firm-years is very large in statistical terms, a wide range of small and micro companies are excluded.

A more recent study by Givoly et al. (2010) examines the difference between companies with public equity and those with private equity for the period 1978-2003. The results are mixed. As in Ball and Shivakumar (2005), they find that public equity companies appear to be superior in loss recognition tests. However, they also find that public equity companies undertake more earnings management, and report more opportunistically, than private companies. This serves to underline that loss recognition tests may not be a good proxy for more broadly based earnings quality measures.

\subsection{Earnings quality across different reporting regimes}

A number of other studies allow the reporting regime to vary across the sample, and are therefore more relevant to the current study. Burgstahler et al. (2006) investigate public and private companies from 1997 to 2003 across European countries. They find that private companies exhibit higher levels of earnings management than public companies. 
JAAR

19,1

However, the study may not have implications for our current issue for two reasons. First, the unit of observation is the industry in a particular country, resulting in a maximum of 269 observations for the tests, which are, therefore, unlikely to capture variations across companies. Second, the findings are for the aggregate sample, and therefore may be driven by differences between countries rather than differences across companies within a given country (e.g. if the ratio of public to private companies is different across countries).

Hope et al. (2013) compares US public and private companies from 2001 to 2009. Their sample is more representative of the small company sector than in prior US work; the median of total assets of private companies is $\$ 4.27 \mathrm{~m}$ compared with $\$ 337 \mathrm{~m}$ in Givoly et al.'s (2010) study. Hope et al. (2013) use a variety of earnings quality measures which show that public companies have higher earnings quality. However, when the tests are focussed on areas where companies are more likely to have managed earnings, they find that the superior earnings quality of public companies disappears.

\subsection{Regime switching and audit exemption}

We have not been able to identify research which directly examines the consequences of switching between different regimes in the UK. However, the issue is an example of a general concern of whether managers use accounting discretion to inform stakeholders or to behave opportunistically. Recent evidence here is based on the US experience and is mixed. For example, despite predictions that managerial discretion in determining goodwill write-offs would be used to convey private information on future cash flows, Ramanna and Watts (2012) and Li and Sloan (2015) find no evidence for this. In contrast, Hanley and Hoberg (2012) find that greater disclosure before an initial public offering is informative and results in more accurate offer pricing. This is particularly relevant to our study since private companies may attempt to improve the quality of reporting by switching to IFRS in anticipation of a public listing. However, Daske et al. (2013) distinguish between "label" and "serious" adopters of IFRS, and it is only the latter type of companies which benefit. From all the above evidence, it is difficult to predict the effect of switching within the UK multi-tier regime.

On the issue of audit exemption, Dedman and Kausar (2012) analyse the behaviour of the companies which became exempt in 2004. They find that those opting out of the audit had higher levels of discretionary accruals in the following year, leading to an upward shift in reported profit. However, the sample is very small (some 4,873 companies) and the coefficients, although statistically significant, are, in economic terms, extremely small. Furthermore, the companies they investigate are at the larger end of the small/micro company spectrum, since they became eligible for audit exemption only due to changes in the threshold. Therefore, the sample is unlikely to be representative of the population of companies which do not opt for an audit.

\subsection{Research questions}

Overall, the research on the effect of the UK multi-tier structure of reporting is limited. International evidence is mixed. Even where it is based on UK companies, it is dated and therefore does not reflect the current environment in which exemptions for some classes of company are substantial. Furthermore, very small companies, which constitute the vast majority, are excluded from the analysis. The study of the impact of audit exemption in the UK is similarly biased against very small companies. There is no direct evidence on the ability of private companies to switch between regimes. However, it is an illustration of the more general issue of whether managers use accounting discretion to inform stakeholders or to behave opportunistically; the evidence here is mixed.

In view of the lack of clear implications either from prior research or from the statements of UK regulators, as discussed above, we identify three key questions in the context of the 
UK regulatory framework. These questions are addressed within the reporting structure in which listed companies applied IFRS, large private and medium-sized companies applied UK GAAP, and small and micro companies applied the FRSSE. Although there have been recent changes in the standards for private companies[3], it will be some time before a large enough data set is available based on these requirements.

The first question relates to the regimes under which the different classes of company were expected to report:

$R Q 1$. Did the structure of UK financial reporting (in which listed companies reported under IFRS, large private and medium-sized companies reported under UK GAAP, small and micro companies reported under the FRSSE) give rise to variations in earnings quality?

The second question concerns the option for non-listed companies to switch between these reporting regimes.

RQ2. Did the regulations which allowed large private and medium-sized companies to switch to IFRS from UK GAAP (and back again), and which allowed small and micro companies to switch to IFRS or UK GAAP (and back again) result in an improvement, a reduction or no change in earnings quality?

The third question is associated with the option for small and micro companies to present unaudited accounts.

RQ3. Did the regulations which allowed small and micro companies to report unaudited accounts give rise to changes in earnings quality?

\section{Research design and data used}

\subsection{Measuring the smoothness of earnings}

We use earnings quality to assess the impact of the multi-tier reporting regime. Our measure of earnings quality is the smoothness of earnings and is based on Lang et al. (2003) and Barth et al. (2008). Standard setters adopt accruals accounting since the volatility of cash flow may mask underlying performance. However, accruals are not desirable if they smooth out the underlying performance itself (Dechow et al., 2010). A common perception is that smooth earnings are appreciated by investors, and even that smooth earnings can reduce the cost of capital (Francis et al., 2004); however, more recent evidence argues that this conclusion is unreliable, due to errors in measuring the cost of capital (McInnis, 2010). Furthermore, from a theoretical perspective, earnings management is likely to decrease a stock's liquidity, and thereby increase the cost of capital (Ascioglu et al., 2012).

There is consistent evidence that smoothing is negatively related to earnings quality. In particular, Ball and Shivakumar $(2005,2006)$ suggest that timely recognition of gains and losses tends to increase the volatility of earnings relative to cash flows. Ewert and Wagenhofer $(2005,2011)$ show that accounting standards that limit opportunistic discretion should result in a higher variability of reported earnings; and Khalil and Simon (2014) find that smoothness is positively related to discretionary accruals. Furthermore, the lack of smoothness is important since the ability of the reporting process to indicate change is a function which is valued by investors (see Barker and Imam, 2008, p. 321). All this suggests that smoothness is an appropriate measure of earnings quality for this study[4].

The smoothness of earnings is a firm-specific time series concept. However, there are drawbacks to measuring smoothness at the firm level, primarily the selection bias arising from the need to obtain a sufficient number of observations and the implied stability of the coefficients over time. Our approach is to include a time dimension by examining the change 
JAAR 19,1

in earnings, which is then set in the context of other companies in a cross-section, controlling for extraneous variables, following Lang et al. (2003) and Barth et al. (2008). A preliminary first step in identifying the smoothness of earnings in each group of companies is to mitigate the effect of economic factors by regressing the change in annual net income scaled by total assets on a number of control variables. The variance of the residuals from this regression $[V(\Delta \mathrm{NI})]$ is then used as an estimate of the smoothness of earnings for the group. A smaller $V(\Delta \mathrm{NI})$ is an indication of earnings smoothness. Specifically, we run the following regression for each group to examine earnings smoothness:

$$
\Delta \mathrm{NI}_{i, t}=\alpha_{0}+\alpha_{1} \text { Size }_{i, t}+\alpha_{2} \text { Growth }_{i, t}+\alpha_{3} \operatorname{Lev}_{i, t}+\alpha_{4} \text { Dissue }_{i, t}+\alpha_{5} \text { Turn }_{i, t}+\alpha_{6} \mathrm{CF}_{i, t}+v_{i, t}
$$

where $\Delta \mathrm{NI}$ is the change in net income scaled by total assets; Size is the natural logarithm of end-of-year value of equity; Growth is the percentage change in sales; Lev is the end-of-year total liabilities divided by end-of-year equity book value; Dissue is the percentage change in total liabilities; Turn is sales divided by end-of-year total assets; and CF is the cash flow from operating activities divided by end-of-year total assets; $i$ takes values in the range $1, \ldots, n_{t}$; and $t$ takes values in the range 2006, 2007, .., 2013. Following the study of Dechow (1994) and Hope et al. (2013), and taking note of there being no requirement for a cash flow statement to be prepared by SMEs, we define the cash flows from operations as $\mathrm{CFO}=E+$ Dep $-\mathrm{WCA}$, where CFO is cash flow from operation for the year; $E$ is profit after tax and extraordinary items for the year; Dep is depreciation (amortisation) for the year; and WCA is working capital accruals, measured as the change in non-cash current assets minus the change in current liabilities other than short-term debt and taxes payable.

A potential weakness of the $V(\Delta \mathrm{NI})$ measure is the way in which it controls for the economic factors which may affect the smoothness of earnings. Although the variables are firm specific, the coefficients of the model are estimated across the entire sample. This procedure is, therefore, unlikely to eliminate all the economic components of smoothness which operate at the firm level; consequently, the regression residual is likely to contain both firm-specific economic as well as accounting factors which affect smoothness. Our test mitigates this confounding of economic and accounting factors, and is again based on Lang et al. (2003) and Barth et al. (2008). We compare the smoothness of the change in net income, $V(\Delta \mathrm{NI})$ from Equation (1), with the smoothness of the change in cash flow from operations, which is estimated in a similar way to the smoothness of earnings equation[5], but with $\Delta \mathrm{CF}$ as the dependent variable, as follows:

$$
\Delta \mathrm{CF}_{i, t}=\alpha_{0}+\alpha_{1} \text { Size }_{i, t}+\alpha_{2} \text { Growth }_{i, t}+\alpha_{3} \operatorname{Lev}_{i, t}+\alpha_{4} \text { Dissue }_{i, t}+\alpha_{5} \operatorname{Turn}_{i, t}+\alpha_{6} \mathrm{CF}_{i, t}+v_{i, t}
$$

where $\Delta \mathrm{CF}$ is the change in cash from operations scaled by total assets. We obtain the variance of residual from Equation (2), $[V(\Delta \mathrm{CF})]$, as the smoothness of cash flows from operation and combine it with the variance of the residual from Equation (1) $[V(\Delta \mathrm{NI})]$ to construct the ratio $V(\Delta \mathrm{NI}) / V(\Delta \mathrm{CF})$. The intuition behind this is that the term $V(\Delta \mathrm{CF})$, like $V(\Delta \mathrm{NI})$, will contain the firm-specific economic components of cash flow smoothness, since the parameter values are estimated across the sample as before; however, $V(\Delta \mathrm{CF})$ is less likely to contain accounting components of earnings smoothing[6]. Taking the ratio of $V(\Delta \mathrm{NI}) / V(\Delta \mathrm{CF})$ attempts to scale out the firm-specific economic components of earnings smoothing, leaving those that relate to accounting methods. A smaller ratio is an indication of smoother earnings.

In order to compare the differences in earnings variability between each group of companies, following Barth et al. (2008), we estimate the standard error of the ratio $V(\Delta \mathrm{NI}) / V(\Delta \mathrm{CF})$ by a bootstrap procedure as follows. From the original sample, we randomly select (with replacement) a new sample of the same size as the original sample, and estimate Equations (1) and (2) again to obtain $V(\Delta \mathrm{NI}) / V(\Delta \mathrm{CF})$; this procedure is repeated 1,000 times to obtain the 
standard deviation of the estimated sampling distribution, and hence, the standard error of the test statistic which approximates to a normal distribution. The standard deviation and mean of each distribution are reported in the tables[7].

\subsection{The control for self-selection bias in medium-sized, small and micro companies}

Medium-sized, small companies and micro companies may submit abbreviated accounts, with no income statement and cash flow statement. In these cases, we are not able to estimate their earnings quality. However, a number of these companies voluntarily report their income statement and, therefore, presumably not randomly. Since we want to examine earnings quality for these observations, we have to control for the self-selection bias. We do this (Givoly et al., 2010; Szczesny and Valentincic, 2013) by including an inverse Mills ratio as an independent control variable in our earnings quality test. The variables which are expected to affect the probability that the companies will produce a full set of accounts are size and the existence of debt. Larger companies have less to fear from strategic aspects of the business being understood from the income statement; and as debt increases, banks are more likely to require an income statement for setting debt covenants. In order to obtain the inverse Mills ratio, we model the probability of existence of the profit and loss statement by running a probit regression on lagged total assets $\left(\mathrm{TA}_{t-1}\right)$ and lagged debt to asset ratio $\left(\mathrm{DA}_{t-1}\right)$. The variable $\operatorname{Pr}(P / L$ statement) takes a value of 1 if the company has voluntarily provided a profit and loss account, and 0 otherwise. We assume that the decision to produce an income statement is made in the period immediately preceding the current period. The estimated probit model is:

$$
\operatorname{Pr}(P / L \text { statement })=\beta_{0}+\beta_{1} \mathrm{TA}_{t-1}+\beta_{2} \mathrm{DA}_{t-1}+\varepsilon
$$

We then modify our Equations (1) and (2) for medium-sized, small and micro companies by including the inverse Mills ratio (Mills) as an independent control variable for these companies, as follows:

$$
\begin{aligned}
\Delta \mathrm{NI}_{i, t}= & \alpha_{0}+\alpha_{1} \text { Size }_{i, t}+\alpha_{2} \text { Growth }_{i, t}+\alpha_{3} \operatorname{Lev}_{i, t}+\alpha_{4} \text { Dissue }_{i, t} \\
& +\alpha_{5} \operatorname{Turn}_{i, t}+\alpha_{6} \mathrm{CF}_{i, t}+\alpha_{7} \operatorname{Mills}_{i, t}+v_{i, t} \\
\Delta \mathrm{CF}_{i, t}= & \alpha_{0}+\alpha_{1} \text { Size }_{i, t}+\alpha_{2} \text { Growth }_{i, t}+\alpha_{3} \operatorname{Lev}_{i, t}+\alpha_{4} \text { Dissue }_{i, t} \\
& +\alpha_{5} \operatorname{Turn}_{i, t}+\alpha_{6} \mathrm{CF}_{i, t}+\alpha_{7} \operatorname{Mills}_{i, t}+v_{i, t}
\end{aligned}
$$

\subsection{The effects of switching and audit exemption}

In order to estimate the effects of switching, we identify companies switching between UK GAAP and IFRS[8] during the sample period, and examine the earnings quality for the identified companies across different classes of companies. We examine the quality of earnings in the year of the switch by measuring the differences in earnings smoothness between the groups; as before we use Equations (1) and (2) for listed and large private companies, and Equations (4) and (5) for medium-sized, small and micro companies.

The audit exemption thresholds for small companies are currently aligned with accounting thresholds. Therefore, in order to examine the effect of audit exemption on earnings quality, we divide both the small and the micro companies samples into two groups: companies with audited accounts and companies with unaudited accounts. We then apply our earnings smoothness tests to compare companies with audited accounts and those with unaudited accounts for both the small and the micro company groups. 
JAAR 19,1

\subsection{Data and sample selection}

The main data applied in this paper are obtained from the "Financial Analysis Made Easy" (FAME) database supplied by Bureau Van Dijk, a common source of data for work in this area (Ball and Shivakumar, 2005; Dedman and Kausar, 2012; Dedman et al., 2014; Collis, 2012).

In the UK, sections 382 and 465 of the Companies Act 2006 define private companies as small or medium for the purpose of accounting requirements. A micro company[9] is one that satisfies at least two of the following criteria: a turnover of not more than $£ 632,000$; a balance sheet total of not more than $£ 316,000$; and a maximum of 10 employees. A small company is one that satisfies at least two of the following criteria: a turnover of not more than $£ 6.5$ million; a balance sheet total of not more than $£ 3.26$ million; and a maximum of 50 employees. A medium-sized company is one that is not classified as small and satisfies at least two of following criteria: a turnover of not more than $£ 25.9$ million; a balance sheet total of not more than $£ 12.9$ million; and a maximum of 250 employees. A large private company is one that is too large to be medium sized and is not listed. Our sample consists of listed companies together with all of the above company categories.

We document the sample selection procedure in Table I. We obtain companies that have available data between 2006 and 2013[10], selecting publicly listed and private companies

$\begin{array}{lc}\text { Panel A: sample selection from FAME } & \\ \text { All active firms in the FAME database with listing status information } & 3,131,051 \\ \text { Less subsidiaries companies } & 259,447 \\ \text { Less financial services firms } & 7,912 \\ \text { Less firms with qualified accounts } & 2,059 \\ \text { Less firms without a value of total assets in any year, 2006-2013 } & 2,114,134 \\ \text { Initial sample-no. of firms } & 747,499\end{array}$

Panel B: breakdown of sample for earnings quality analysis across size categories

$\begin{array}{ccccll}\begin{array}{l}\text { Listed } \\ \text { firms } \\ \text { private } \\ \text { firms }\end{array} & \begin{array}{l}\text { Medium- } \\ \text { sized }\end{array} & \begin{array}{l}\text { Small } \\ \text { firms }\end{array} & \begin{array}{l}\text { Micro } \\ \text { firms }\end{array} & \text { All firms } \\ 1,419 & 3,448 & 9,023 & 403,693 & 329,916 & 747,499 \\ & & & & & \\ \text { N/A } & \text { N/A } & (764) & (285,639) & (246,429) & (532,832) \\ (290) & (693) & (2,220) & (39,862) & (27,870) & (70,935) \\ 1,129 & 2,755 & 6,039 & 78,192 & 55,617 & 143,732 \\ & & & & & \\ 6,318 & 13,067 & 20,630 & 256,562 & 217,647 & 514,224\end{array}$

Initial sample - no. of firms

accounting regimes

Less: firms filing abbreviated Account

$(\operatorname{Pr}=0)$

Less: firms with missing data

No. of firms used in Equations (1) and (2)

No. of firm-years used in Equations (1)

and (2)

Listed Large
firms private
firms

Medium- Small

Micro

All firms

Panel C: breakdown of sample for switching

No. of firms used in Equations (1) and (2)

$1,129 \quad 2,755$

sized

firms

firms

Firms not switching accounting standards

Firms which followed IFRS

$977 \quad 2,686$

6,039

$\begin{array}{cc}6,039 & 78,192 \\ 5,999 & 78,088 \\ 56 & 111 \\ 5,943 & 77,977 \\ 40 & 104 \\ 37 & 78 \\ 19 & 68\end{array}$

55,617

$977 \quad 132$

$0 \quad 2,554$

Firms switching accounting standards

152

Instances of switching from GAAP to IFRS

Instances of switching from IFRS to GAAP

152

69

65

32

$55,617 \quad 143,367$

$0 \quad 1,276$

$55,617 \quad 142,091$

$0 \quad 365$

Notes: All observations are observed during the sample period, 2006-2013. The instances of switching from GAAP to IFRS plus the instances of switching from IFRS to GAAP may not add up to the number of firms

Table I.

Sample selection switching accounting standards due to firms having multiple switches during the sample period. The instances of switching accounting standards are examined in Table IV panels B and C 
based on their listing status in the FAME classification. The period 2006-2013 is chosen since this includes a period in which the UK economy was weak following the collapse in 2007 (ONS, 2014); the year 2006 is included for comparison. In order to inform future policy, it is important to focus on such periods during which comparability issues may arise due to large one-off items and also earnings management to obscure poor performance. We exclude banks, other financial institutions (SIC codes 6000-6799) and also companies without a known value of total assets between 2006 and 2013 in order to mitigate data errors. We also exclude companies with qualified accounts during the sample period because they are likely to have different reporting incentives. Our initial sample has 747,499 companies. However, due to the lack of companies' data to compute earnings quality measures, the resulting sample is reduced to 514,224 firm-year observations, comprising of 6,318 for listed companies, 13,067 for large private companies, 20,630 for medium-sized companies, 256,562 for small companies and 217,647 for micro companies.

Table II (panels A-E) gives the summary statistics of the accounting variables used in the study. We note that total assets and total sales are more varied for listed companies than for private companies; also, large private companies are more varied in size than the other private groups. Turning to our testing variables, we observe that the standard deviations of $\Delta \mathrm{NI}$ and $\Delta \mathrm{CF}$ are larger for small and micro companies than for large private and mediumsized companies. This suggests that small and micro companies are unlikely to have a higher level of earnings smoothness than others. Furthermore, small and micro companies have negative growth, suggesting that smaller companies are struggling during the period of downturn; they also have higher leverage indicating that they have a greater reliance on debt to finance the business.

\section{Results and analysis}

\subsection{The smoothness of earnings}

Table III presents results of the smoothness of earnings tests for the sample period 2006-2013[11]. For the $V(\Delta \mathrm{NI})$ measure, small and micro companies have higher values than other firms ( 0.1132 for small companies, 0.1707 for micro companies), which suggests that sample wide parameters do not eliminate all the firm-specific economic variability. This is consistent with small and micro companies covering a wide spectrum of economic operations. After scaling by cash flow variability, the $V(\Delta \mathrm{NI}) / V(\Delta \mathrm{CF})$ measure is largest for listed companies (0.3313) closely followed by small and micro companies, 0.2485 and 0.2231 , respectively. The earnings of large private and medium-sized companies are much smoother with relatively low values of 0.0587 and 0.0695 , respectively. We give the standard deviation of the bootstrap distribution as an estimate of the standard error, and the mean for comparison with the sample statistic; the differences discussed above are statistically significant and are also found when we disaggregate across the sample years.

Overall, these results indicate that IFRS is effective in constraining the incentives for earnings management which exist in listed companies. The quality of earnings in small and micro companies is nearly as informative as in listed companies, suggesting that the strategy of giving reporting exemptions to small and micro companies has not lowered earnings quality. In contrast, the earnings of large private and medium-sized companies are significantly smoother, suggesting that their reported performance may not be comparable with that of listed, small and micro companies.

\subsection{The effect of switching between regimes}

In our second test, we rerun the earnings smoothness tests to examine the effect of switching between reporting regimes. Table IV reports the results for firms switching reporting 
JAAR

19,1

12

Table II.

Descriptive statistics

of variables used in the analyses

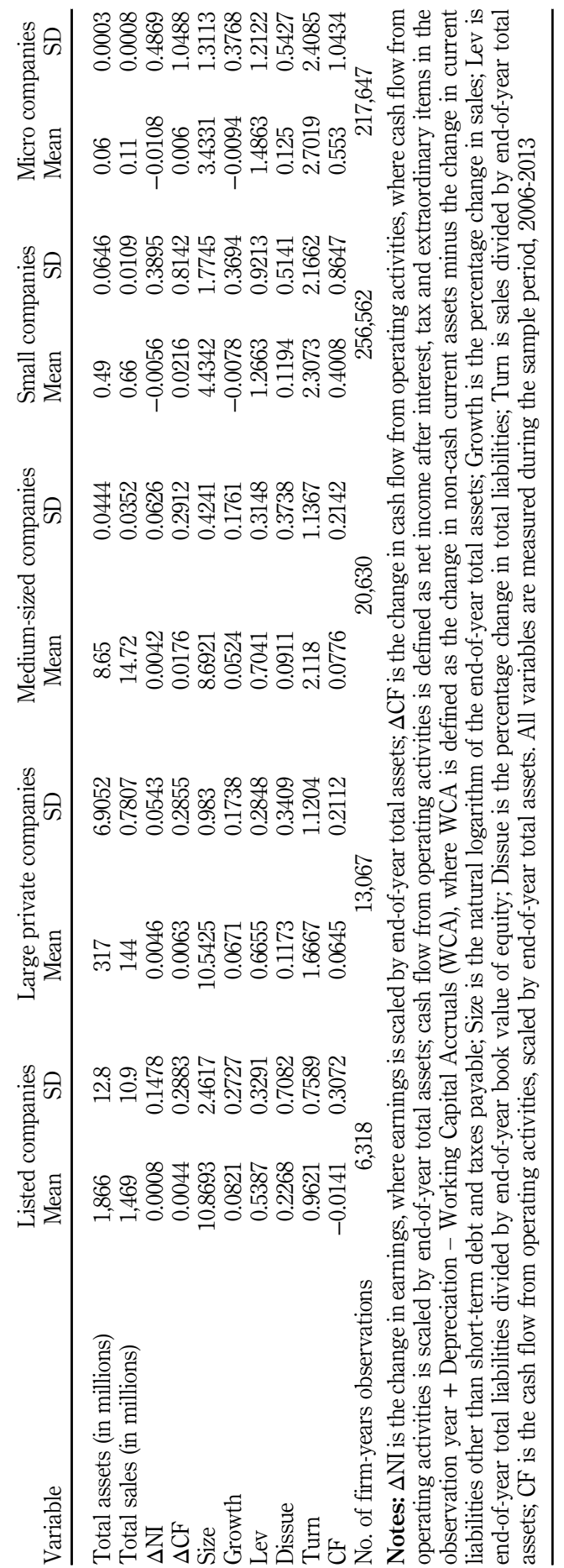




\begin{tabular}{|c|c|c|c|c|c|c|c|}
\hline Year & Variable & $\begin{array}{c}\text { Listed } \\
\text { companies }\end{array}$ & $\begin{array}{l}\text { Large private } \\
\text { companies }\end{array}$ & $\begin{array}{c}\text { Medium } \\
\text { companies }\end{array}$ & $\begin{array}{c}\text { Small } \\
\text { companies }\end{array}$ & $\begin{array}{c}\text { Micro } \\
\text { companies }\end{array}$ & $\begin{array}{r}\text { Earnings } \\
\text { quality }\end{array}$ \\
\hline \multirow[t]{5}{*}{ All years } & No. of firm-years & 6,318 & 13,067 & 20,630 & 256,562 & 217,647 & \\
\hline & $V(\Delta \mathrm{NI})$ & 0.0170 & 0.0027 & 0.0035 & 0.1132 & 0.1707 & \\
\hline & $\mathrm{SD}$, mean of & (1.27E-04, & (1.04E-06, & (1.05E-06, & (1.39E-04, & (2.09E-04, & \\
\hline & $\begin{array}{l}\text { bootstrap distribn } \\
V(\Delta \mathrm{NI}) / V(\Delta \mathrm{CF})\end{array}$ & $\begin{array}{l}0.0169) \\
0.3313\end{array}$ & $\begin{array}{l}0.0027) \\
0.0587\end{array}$ & $\begin{array}{l}0.0035) \\
0.0695\end{array}$ & $\begin{array}{l}0.1132) \\
0.2485\end{array}$ & $\begin{array}{l}0.1707) \\
0.2231\end{array}$ & 13 \\
\hline & $\begin{array}{l}\text { SD, mean of } \\
\text { bootstrap distribn }\end{array}$ & $\begin{array}{c}\text { (3.74-E03, } \\
0.3314)\end{array}$ & $\begin{array}{l}(3.82 \mathrm{E}-04, \\
0.0587)\end{array}$ & $\begin{array}{c}(3.33 \mathrm{E}-04, \\
0.0696)\end{array}$ & $\begin{array}{l}(4.43 \mathrm{E}-04, \\
0.2486)\end{array}$ & $\begin{array}{c}(4.18 \mathrm{E}-04 \\
0.2230)\end{array}$ & \\
\hline \multirow[t]{2}{*}{2006} & No. of firms & 768 & 1,367 & 1,970 & 34,087 & 38,136 & \\
\hline & $V(\Delta \mathrm{NI}) / V(\Delta \mathrm{CF})$ & 0.3199 & 0.0589 & 0.0783 & 0.2474 & 0.2325 & \\
\hline \multirow[t]{2}{*}{2007} & No. of firms & 780 & 1,442 & 2,180 & 33,642 & 39,508 & \\
\hline & $V(\Delta \mathrm{NI}) / V(\Delta \mathrm{CF})$ & 0.3979 & 0.0579 & 0.0715 & 0.2519 & 0.2285 & \\
\hline \multirow{2}{*}{2008} & No. of firms & 780 & 1,575 & 2,249 & 32,945 & 40,240 & \\
\hline & $V(\Delta \mathrm{NI}) / V(\Delta \mathrm{CF})$ & 0.3857 & 0.0771 & 0.0851 & 0.2461 & 0.2266 & \\
\hline \multirow[t]{2}{*}{2009} & No. of firms & 805 & 1,611 & 2,608 & 32,045 & 33,629 & \\
\hline & $V(\Delta \mathrm{NI}) / V(\Delta \mathrm{CF})$ & 0.3620 & 0.0606 & 0.0802 & 0.2500 & 0.2088 & \\
\hline \multirow[t]{2}{*}{2010} & No. of firms & 790 & 1,733 & 2,842 & 31,662 & 18,114 & \\
\hline & $V(\Delta \mathrm{NI}) / V(\Delta \mathrm{CF})$ & 0.2088 & 0.0417 & 0.0549 & 0.2497 & 0.2198 & \\
\hline \multirow[t]{2}{*}{2011} & No. of firms & 807 & 1,744 & 2,984 & 30,941 & 19,686 & \\
\hline & $V(\Delta \mathrm{NI}) / V(\Delta \mathrm{CF})$ & 0.3935 & 0.0649 & 0.0672 & 0.2458 & 0.2257 & \\
\hline \multirow{2}{*}{2012} & No. of firms & 794 & 1,793 & 2,958 & 30,698 & 15,335 & \\
\hline & $V(\Delta \mathrm{NI}) / V(\Delta \mathrm{CF})$ & 0.4001 & 0.0594 & 0.0762 & 0.2455 & 0.2315 & \\
\hline \multirow[t]{2}{*}{2013} & No. of firms & 794 & 1,802 & 2,839 & 30,542 & 12,999 & \\
\hline & $V(\Delta \mathrm{NI}) / V(\Delta \mathrm{CF})$ & 0.3789 & 0.0595 & 0.0730 & 0.2448 & 0.2232 & \\
\hline \multicolumn{8}{|c|}{$\begin{array}{l}\text { Notes: } V(\Delta \mathrm{NI}) \text { is the variability of earnings, which is measured by the variance of the residuals from } \\
\text { Equations }(1) \text { and }(4) \text { to capture the smoothness of earnings; } V(\Delta \mathrm{NI}) / V(\Delta \mathrm{CF}) \text { is the ratio of variability of } \\
\text { earnings to the variability of cash flows from operating activities, where the variability of earnings is } \\
\text { measured by the variance of the residuals from Equations (1) and }(4) \text {, and the variability of cash flows is } \\
\text { measured by the variance of the residuals from Equations }(2) \text { and }(5) \text {. This ratio is to capture the smoothness } \\
\text { of earnings related to the smoothness of cash flows. We report, in parenthesis, the means and standard } \\
\text { deviations of the bootstrapped variance of residuals }[V(\Delta \mathrm{NI})] \text { and the ratio }[V(\Delta \mathrm{NI}) / V(\Delta \mathrm{CF})] \text {. The standard } \\
\text { deviation of the bootstrap distribution is our estimate of the standard error of the test statistic which } \\
\text { approximates to a normal distribution. All variables are measured during the sample period, 2006-2013 }\end{array}$} \\
\hline
\end{tabular}

regimes during the sample period 2006-2013. For comparison, panels $A, A(1)$ and $A(2)$ report the results for companies which did not change regime, and is consistent with Table III; that is, large private and medium-sized companies appear to have a lower quality of earnings than other groups. In addition, panel A(1) shows that following IFRS does not guarantee earnings quality since there is variation across the different types of companies; these results are similar to Kvaal and Nobes (2012) who document the variation in accounting practice across European countries, even though they are all following IFRS.

Table IV panel B gives the results for companies which switched from UK GAAP to IFRS. Since IFRS was compulsory for listed companies for accounting periods commencing 1 January 2005, the 152 observations identified for listed companies are presumably those which became listed during the sample period. Table IV panel B also shows that the large private companies which voluntarily switched to IFRS improved their earnings quality very slightly, since they have a smoothing measure of 0.0722 compared with 0.0537 for those which followed UK GAAP, as shown in panel A(2). It is possible that these large private companies may have been considering listed status and, thus, improved their reporting quality to gain more accurate offer pricing in the future, as found by Hanley and Hoberg (2012). In contrast, the small- and medium-sized companies which switched to IFRS have 
JAAR
19,1

Table IV.

The effect of switching regimes on earnings quality for different groups of companies

\begin{tabular}{lccccc}
\hline Variable & $\begin{array}{c}\text { Listed } \\
\text { companies }\end{array}$ & $\begin{array}{c}\text { Large private } \\
\text { companies }\end{array}$ & $\begin{array}{c}\text { Medium } \\
\text { companies }\end{array}$ & $\begin{array}{c}\text { Small } \\
\text { companies }\end{array}$ & $\begin{array}{c}\text { Micro } \\
\text { companies }\end{array}$ \\
\hline
\end{tabular}

Panel A: observations where there is no change accounting standards during the sample period

\begin{tabular}{|c|c|c|c|c|c|}
\hline No. of firm-years & 5,466 & 12,725 & 20,500 & 256,142 & 217,647 \\
\hline$V(\Delta \mathrm{NI}) / V(\Delta \mathrm{CF})$ & 0.3311 & 0.0582 & 0.0719 & 0.2486 & 0.2231 \\
\hline $\begin{array}{l}\text { SD, mean of } \\
\text { bootstrap distribn }\end{array}$ & $\begin{array}{c}(4.37 \mathrm{E}-03, \\
0.3316)\end{array}$ & $\begin{array}{c}(4.19 \mathrm{E}-04, \\
0.0582)\end{array}$ & $\begin{array}{c}(4.33 \mathrm{E}-04, \\
0.0720)\end{array}$ & $\begin{array}{c}(4.18 \mathrm{E}-04, \\
0.2486)\end{array}$ & $\begin{array}{r}(4.18 E-0 \\
0.2230)\end{array}$ \\
\hline
\end{tabular}

Panel A (1): observations for companies which followed IFRS during the sample period

$\begin{array}{lcccc}\text { No. of firm-years } & 5,466 & 651 & 182 & 531 \\ V(\Delta \mathrm{NI}) / V(\Delta \mathrm{CF}) & 0.3311 & 0.0587 & 0.0806 & 0.1795 \\ \mathrm{SD}, \text { mean of } & (4.37 \mathrm{E}-03, & (1.60 \mathrm{E}-03, & (4.19 \mathrm{E}-03, & (8.91 \mathrm{E}-03, \\ \text { bootstrap distribn } & 0.3316) & 0.0586) & 0.0812) & 0.1804)\end{array}$

Panel A (2): observations for companies which followed UK GAAP during the sample period

\begin{tabular}{|c|c|c|c|c|c|}
\hline No. of firm-years & - & 12,074 & 20,318 & 255,611 & 217,647 \\
\hline$V(\Delta \mathrm{NI}) / V(\Delta \mathrm{CF})$ & - & 0.0537 & 0.0718 & 0.2487 & 0.2231 \\
\hline $\begin{array}{l}\text { SD, mean of } \\
\text { bootstrap distribn }\end{array}$ & - & $\begin{array}{c}(4.53 \mathrm{E}-04, \\
0.0540)\end{array}$ & $\begin{array}{c}(4.24 \mathrm{E}-04 \\
0.0718)\end{array}$ & $\begin{array}{c}(4.05 \mathrm{E}-04 \\
0.2486)\end{array}$ & $\begin{array}{c}(4.18 E-04, \\
0.2230)\end{array}$ \\
\hline
\end{tabular}

Panel B: observations for companies which changed accounting standards from UK GAAP to IFRS during the sample period

No. of firm-year

$V(\Delta \mathrm{NI}) / V(\Delta \mathrm{CF})$

$\mathrm{SD}$, mean of bootstrap distribn

$\begin{array}{cccc}152 & 65 & 37 & 78 \\ 0.2891 & 0.0722 & 0.0178 & 0.1605 \\ (1.74 \mathrm{E}-02, & (6.73 \mathrm{E}-03, & (5.51 \mathrm{E}-03, & (3.08 \mathrm{E}-02, \\ 0.2930) & 0.0759) & 0.0217) & 0.1522)\end{array}$

Panel C: observations for companies which changed accounting standards from IFRS to UK GAAP during the sample period

No. of firm-years

$V(\Delta \mathrm{NI}) / V(\Delta \mathrm{CF})$

$\mathrm{SD}$, mean of

32
0.0277
$(1.04 \mathrm{E}-02$
$0.0363)$

19
0.0150
$(2.31 \mathrm{E}-02$
$0.1571)$

68
0.1421
$(5.56 \mathrm{E}-01$,
$0.1750)$

bootstrap distribn $\quad 0.0363) \quad 0.1571) \quad 0.1750)$

Notes: $V(\Delta \mathrm{NI})$ is the variability of earnings, which is measured by the variance of the residuals from Equations (1) and (4) to capture the smoothness of earnings; $V(\Delta \mathrm{NI}) / V(\Delta \mathrm{CF})$ is the ratio of variability of earnings to the variability of cash flows from operating activities, where the variability of earnings is measured by the variance of the residuals from Equations (1) and (4), and the variability of cash flows is measured by the variance of the residuals from Equations (2) and (5). This ratio is to capture the smoothness of earnings related to the smoothness of cash flows. We report, in parenthesis, the means and standard deviations of the bootstrapped variance of residuals $[V(\Delta \mathrm{NI})]$ and the ratio $[V(\Delta \mathrm{NI}) / V(\Delta \mathrm{CF})]$. The standard deviation of the bootstrap distribution is our estimate of the standard error of the test statistic which approximates to a normal distribution. Variables in panel A are measured during the sample period, 2006-2013. Variables in panels B and C are measured during the year of the switch

smoother earnings than those companies which followed UK GAAP during the period; small companies have a smoothing value of 0.1605 compared with 0.2487 in panel $\mathrm{A}(2)$, whilst medium-sized companies have a smoothing value of 0.0178 compared with 0.0718 in panel $\mathrm{A}(2)$. This is suggestive of a situation in which companies switch to IFRS without any accompanying improvement in reporting quality.

Table IV panel $\mathrm{C}$ shows that all the private companies (small, medium-sized and large) which switched back from IFRS to UK GAAP have more earnings smoothing than those which remained with UK GAAP, as shown in panel $\mathrm{A}(2)$. The overall conclusion about switching is that, with the exception of large private companies which slightly reduced smoothing by switching to IFRS (perhaps in anticipation of an initial public offering), the evidence from both panels $\mathrm{B}$ and $\mathrm{C}$ suggests that switching (in whatever direction) reduces earnings quality. 


\subsection{The effect of audit exemption}

Table $\mathrm{V}$ presents the effect of audit exemption on earnings quality. A feature of the results is that the trend away from audit, documented by Dedman et al. (2014) for the years 2003-2006, continues. For small companies, in 2006, there were 17,245 companies which had an audit compared with 16,842 which did not; by 2013, the numbers were 2,907 and 27,635, respectively. The story for micro companies is similar. These numbers also document the decline of both small and micro companies during the recession.

With respect to small companies, for all years combined, the $V(\Delta \mathrm{NI}) / V(\Delta \mathrm{CF})$ measure in Table V shows that audited accounts have much the same earnings smoothness (0.2472) as small company non-audited accounts (0.2491). This finding is along similar lines to those of vanTendeloo and Vanstraelen (2008), who, in a European study of private companies 1998-2002, find that earnings smoothing in the UK does not vary much between Big 4 and nonBig 4 audited companies. However, we find that, in recent years, small company audited accounts are slightly smoother than non-audited accounts; for example, in 2011, the smoothness measure was 0.2170 compared with 0.2475 for non-audited accounts, which suggests that the disciplining effect of audit on earnings quality was slightly weakened after the recession period.

Table V also shows the results for micro companies. For all years combined, audited micro companies appear to have similar earnings quality to unaudited micro companies;

\begin{tabular}{|c|c|c|c|c|c|}
\hline \multirow[b]{2}{*}{ Year } & \multirow[b]{2}{*}{ Variable } & \multicolumn{2}{|c|}{ Small companies } & \multicolumn{2}{|c|}{ Micro companies } \\
\hline & & $\begin{array}{l}\text { Audited } \\
\text { accounts }\end{array}$ & $\begin{array}{l}\text { Non-audited } \\
\text { accounts }\end{array}$ & $\begin{array}{l}\text { Audited } \\
\text { accounts }\end{array}$ & $\begin{array}{l}\text { Non-audited } \\
\text { accounts }\end{array}$ \\
\hline \multirow[t]{5}{*}{ All Years } & No. of firm-years & 75,976 & 180,586 & 72,111 & 145,536 \\
\hline & $V(\Delta \mathrm{NI})$ & 0.0996 & 0.1193 & 0.1692 & 0.1715 \\
\hline & $\begin{array}{l}\text { Mean, SD of } \\
\text { bootstrap distribn }\end{array}$ & $(0.1067,2.63 \mathrm{E}-04)$ & $(0.1154,1.59 \mathrm{E}-04)$ & $(0.1691,3.67 \mathrm{E}-04)$ & $(0.1714,2.70 \mathrm{E}-04)$ \\
\hline & $V(\Delta \mathrm{NI}) / V(\Delta \mathrm{CF})$ & 0.2472 & 0.2491 & 0.2278 & 0.2211 \\
\hline & $\begin{array}{l}\text { Mean, SD of } \\
\text { bootstrap distribn }\end{array}$ & $(0.2507,8.68 \mathrm{E}-04)$ & $(0.2478,5.16 \mathrm{E}-04)$ & $(0.2279,7.53 \mathrm{E}-04)$ & $(0.2211,4.85 \mathrm{E}-04)$ \\
\hline \multirow[t]{2}{*}{2006} & No. of firms & 17,245 & 16,842 & 18,209 & 20,272 \\
\hline & $V(\Delta \mathrm{NI}) / V(\Delta \mathrm{CF})$ & 0.2527 & 0.2429 & 0.2364 & 0.2278 \\
\hline \multirow[t]{2}{*}{2007} & No. of firms & 16,706 & 16,936 & 18,587 & 20,806 \\
\hline & $V(\Delta \mathrm{NI}) / V(\Delta \mathrm{CF})$ & 0.2464 & 0.2566 & 0.2331 & 0.2252 \\
\hline \multirow[t]{2}{*}{2008} & No. of firms & 15,654 & 17,291 & 19,136 & 20,989 \\
\hline & $V(\Delta \mathrm{NI}) / V(\Delta \mathrm{CF})$ & 0.2490 & 0.2433 & 0.2280 & 0.2254 \\
\hline \multirow[t]{2}{*}{2009} & No. of firms & 13,047 & 18,998 & 13,304 & 20,210 \\
\hline & $V(\Delta \mathrm{NI}) / V(\Delta \mathrm{CF})$ & 0.2456 & 0.2520 & 0.2127 & 0.2062 \\
\hline \multirow[t]{2}{*}{2010} & No. of firms & 3,835 & 27,827 & 941 & 17,173 \\
\hline & $V(\Delta \mathrm{NI}) / V(\Delta \mathrm{CF})$ & 0.2353 & 0.2504 & 0.2204 & 0.2196 \\
\hline \multirow[t]{2}{*}{2011} & No. of firms & 3,370 & 27,571 & 728 & 18,958 \\
\hline & $V(\Delta \mathrm{NI}) / V(\Delta \mathrm{CF})$ & 0.2170 & 0.2475 & 0.2611 & 0.2257 \\
\hline \multirow[t]{2}{*}{2012} & No. of firms & 3,212 & 27,486 & 627 & 14,708 \\
\hline & $V(\Delta \mathrm{NI}) / V(\Delta \mathrm{CF})$ & 0.1897 & 0.2501 & 0.2744 & 0.2317 \\
\hline \multirow[t]{2}{*}{2013} & No. of firms & 2,907 & 27,635 & 579 & 12,420 \\
\hline & $V(\Delta \mathrm{NI}) / V(\Delta \mathrm{CF})$ & 0.2293 & 0.2463 & 0.3470 & 0.2203 \\
\hline
\end{tabular}

Notes: $V(\Delta \mathrm{NI})$ is the variability of earnings, which is measured by the variance of the residuals from Equations (1) and (4) to capture the smoothness of earnings; $V(\Delta \mathrm{NI} / V(\Delta \mathrm{CF})$ is the ratio of variability of earnings to the variability of cash flows from operating activities, where the variability of earnings is measured by the variance of the residuals from Equations (1) and (4), and the variability of cash flows is measured by the variance of the residuals from Equations (2) and (5). This ratio is to capture the smoothness of earnings related to the smoothness of cash flows. We report, in parenthesis, the means and standard deviations of the bootstrapped variance of residuals $[V(\Delta \mathrm{NI})]$ and the ratio $[V(\Delta \mathrm{NI}) / V(\Delta \mathrm{CF})]$. The standard deviation of the bootstrap distribution is our estimate of the standard error of the test statistic which approximates to a normal distribution. All variables are measured during the sample period, 2006-2013
Earnings quality
Table V.

The effect of audit on earnings quality for small and micro companies 
JAAR

19,1

the $V(\Delta \mathrm{NI}) / V(\Delta \mathrm{CF})$ measure is similar for both groups ( 0.2278 and 0.2211 , respectively). At the individual year level, there is evidence that the audit improves earnings quality. For 2011-2013, the $V(\Delta \mathrm{NI}) / V(\Delta \mathrm{CF})$ measure is larger for audited accounts than for unaudited accounts; the greatest difference is in 2013, when for a small number of companies (579), the ratio was 0.3470 compared with 0.2203 for non-audited accounts. Although the explanation for this is beyond the current paper, it is noteworthy that the period is one in which the number of micro companies is declining. It may be that in this context, some micro companies were in need of finance from banks, which require good-quality financial information, including an audit.

\section{Conclusions}

Since the Companies Act 1981, there has emerged a multi-tier framework for financial reporting in the UK. This development was extended by the 2013 Accounting Directive from the EU, which has the objective of reducing disproportionate costs imposed on smaller companies. An important issue which arises from this multi-tier approach is how the quality of reporting is affected.

UK regulation itself offers no guidance on this question and the existing research is both limited and dated. In particular, the studies exclude very small and micro companies which are the focus of the $2013 \mathrm{EU}$ directive, requiring the reporting burden to be reduced for this group. We address this gap in the literature and review the quality of earnings between the different types of company from 2006 to 2013. We classify companies according to whether they are listed, large private, medium-sized, small or micro. The inclusion of very small and micro companies leads to a large sample of over 514,000 company-year observations. Earnings quality is measured by its lack of smoothness, which is a general measure and recognised to reflect the quality of accounting standards and the needs of stakeholders.

We find that the earnings of listed companies have the highest quality reflecting the success of IFRS in restraining the well-recognised incentives for earnings management. This is closely followed by small and micro companies. In contrast, the smoothing behaviour of large private and medium-sized companies is approximately six times as large as listed companies and four times as large as small and micro companies. This finding is consistent with opportunistic behaviour undertaken by large private and medium-sized companies having transactions for which there is more discretion under UK GAAP than under IFRS.

A feature of UK standards is that non-listed companies are allowed to report under a regime intended for larger companies; for example, medium-sized companies may report using IFRS instead of UK GAAP. We find that the number of companies which switch regimes is small. Large private companies which switched to IFRS have improved earnings quality; they may have been considering listed status and, thus, improved their reporting quality to gain more accurate offer pricing in the future. Switching by other private companies suggests opportunism. Medium-sized companies that switch regime, whether from or back to the home regime, have the poorest earnings quality of all medium-sized companies. Similarly, small companies which remain in their home regime and follow UK GAAP have a higher earnings quality than other small companies.

Another flexibility, allowed only to small and micro companies, is to be exempt from audit. We assess whether exercising this option leads to a decline in quality. Overall, the results indicate that earnings quality is much the same for both audited and unaudited financial statements, suggesting that small and micro companies act in the best interests of their stakeholders even when they are not under the audit spotlight. However, we also find some indication, for the more recent 2011-2013 period, that micro companies which choose an audit have a higher earnings quality than those which do not. We do not investigate the cause of this, but perhaps it is related to the increased demand by micro companies for bank finance after the 2008 recession. 
Two reservations are in order. First, we have not been able to measure the impact of the option for micro-, small- and medium-sized companies to submit abbreviated accounts since we assess companies according to their earnings quality and the companies involved do not file an income statement. From a policy viewpoint, this limitation may not be too critical since the option is likely to be exercised less frequently when, from 2016, shareholder approval is required every year. Second, our analysis is based on reporting requirements prior to the recently issued FRS 102/FRS 105 for medium sized, small and micro companies. However, it will be some time before suitable data are available based on those standards. Therefore, given the stability of our results over time and the very limited evidence to date, we believe that this study gives some worthwhile insight into answering the question of whether the directive is a "sensible reduction in red tape or a source of risk to the UK economy" (ICAEW, 2015). Overall, our results, based on past evidence, show that it is possible to reduce the reporting burden on small and micro companies without compromising the quality of reporting.

\section{Notes}

1. These large- and medium-sized companies, as well as small companies, were also permitted to report under IFRS if they so wished. However, the Companies Act 2006, s395 and s403 placed restrictions on switching back to the home regime, but these were subsequently relaxed to allow companies to switch back within a five year period.

2. The Accounting Standards Board (ASB) was the chief regulatory body for accounting standards in the UK prior to the reorganisation in July 2012 when it was superseded by the Financial Reporting Council (FRC).

3. Large private and medium-sized companies are intended to report under FRS 102 (effective from 1 January 2015), small companies under a special section of FRS 102 and micro companies under FRS 105 (effective from 1 January 2016).

4. In common with studies in this area, we concentrate on recognition rather than disclosure, since research (e.g. Schipper, 2007) suggests that disclosure does not compensate for inadequate recognition.

5. As in Barth et al. (2008), the values of the variables below the 5th percentile and above the 95th level are winsorized to mitigate the influence of outliers.

6. However, to the extent that the control variables are inadequately measured by the accounting system, $V(\Delta C F)$ may still be contaminated by accounting factors.

7. We also report the statistics for $V(\Delta N I)$ which are constructed in a similar way.

8. The FAME database: we use records only whether a company follows UK GAAP or IFRS, and not whether the FRSEE is adopted within UK GAAP.

9. The Companies Act 2006 was amended by statutory instrument, SI, 3008, The Small Companies (Micro Entities' Accounts) Regulations 2013.

10. We also need prior year data to calculate changes in working capital, but this is not part of our sample period for the smoothing tests.

11. Of note is the fact that earnings quality for 2006 and 2007 is similar for all types of company, suggesting that the $V(\Delta \mathrm{NI}) / V(\Delta \mathrm{CF})$ measure is able to eliminate volatility due to the recession which commenced in 2007.

\section{References}

Ascioglu, A., Hegde, S., Krishnan, G. and McDermott, J. (2012), "Earnings management and market liquidity", Review of Quantitative Finance and Accounting, Vol. 38 No. 2, pp. 257-274.

Ball, R. and Shivakumar, L. (2005), "Earnings quality in UK private firms: comparative loss recognition timeliness", Journal of Accounting and Economics, Vol. 39 No. 1, pp. 83-128. 
JAAR 19,1

Ball, R. and Shivakumar, L. (2006), "The role of accruals in asymmetrically timely gain and loss recognition", Journal of Accounting Research, Vol. 44 No. 2, pp. 207-242.

Barker, R. and Imam, S. (2008), “Analysts' perceptions of earnings quality”, Accounting and Business Research, Vol. 38 No. 4, pp. 313-329.

Barth, M.E., Landsman, W.R. and Lang, M.H. (2008), "International accounting standards and accounting quality", Journal of Accounting Research, Vol. 46 No. 3, pp. 467-498.

Beatty, A.L., Ke, B. and Petroni, K.R. (2002), "Earnings management to avoid earnings declines across publicly and privately held banks", Accounting Review, Vol. 77 No. 3, pp. 547-570.

Burgstahler, D.C., Hail, L. and Leuz, C. (2006), "The importance of reporting incentives: earnings management in European private and public firms", Accounting Review, Vol. 81 No. 5, pp. 983-1016.

Chopping, D. and Skerratt, L. (1997), Applying GAAP 1997/98, Accountancy Books, Milton Keynes, p. 585.

Collis, J. (2012), "Determinants of voluntary audit and voluntary full accounts in micro and non micro small companies in the UK", Accounting and Business Research, Vol. 42 No. 4, pp. 441-468.

Daske, H., Hail, L., Leuz, C. and Verdi, R. (2013), "Adopting a label: heterogeneity in the economic consequences around IAS/IFRS adoptions”, Journal of Accounting Research, Vol. 51 No. 3, pp. 495-547.

Dechow, P., Ge, W. and Schrand, C. (2010), "Understanding earnings quality: a review of the proxies, their determinants and their consequences", Journal of Accounting and Economics, Vol. 50 No. 2, pp. 344-401.

Dechow, P.M. (1994), "Accounting earnings and cash flows as measures of firm performance: the role of accounting accruals", Journal of Accounting and Economics, Vol. 18 No. 1, pp. 3-42.

Dedman, E. and Kausar, A. (2012), "The impact of voluntary audit on credit ratings: evidence from UK private firms", Accounting and Business Research, Vol. 42 No. 4, pp. 397-418.

Dedman, E., Kausar, A. and Lennox, C. (2014), "The demand for audit in private firms: recent largesample evidence from the UK", European Accounting Review, Vol. 23 No. 1, pp. 1-23.

European Union (2012), "Directive 2012/6/EU of the European Parliament and of the council of 14 March 2012, amending council directive 78/660/EEC on the annual accounts of certain types of companies as regards micro entities", Official Journal of the European Union, L81, pp. 4-5.

European Union (2013), "Directive 2013/34/EU of the European Parliament and of the council of 26 June 2013 on the annual financial statements, consolidated financial statements and related reports of certain types of undertakings, amending directive 2006/43/EC of the European Parliament and of the council and repealing council directives 78/660/EEC and 83/349/EEC", Official Journal of the European Union, L182, p. 28.

Ewert, R. and Wagenhofer, A. (2005), "Economic effects of tightening accounting standards to restrict earnings management", The Accounting Review, Vol. 80 No. 4, pp. 1101-1124.

Ewert, R. and Wagenhofer, A. (2011), "Earnings quality metrics and what they measure", working paper, University of Graz, Graz, available at: http://ssrn.com/abstract=1697042 (accessed 12 March 2016).

Francis, J., LaFond, R., Olsson, P. and Schipper, K. (2004), “Costs of equity and earnings attributes”, The Accounting Review, Vol. 79 No. 4, pp. 967-1010.

FRC (2015), "FRS 102: the financial reporting standard applicable in the UK and Republic of Ireland", Financial Reporting Council, London.

Givoly, D., Hayn, C. and Katz, S. (2010), "Does public ownership of equity improve earnings quality?", The Accounting Review, Vol. 85 No. 1, pp. 195-225.

Hanley, K. and Hoberg, G. (2012), "Litigation risk, strategic disclosure and the underpricing of initial public offerings", Journal of Financial Economics, Vol. 103 No. 2, pp. 235-254.

Hope, O.K., Thomas, W.B. and Vyas, D. (2013), "Financial reporting quality of US private and public firms”, The Accounting Review, Vol. 88 No. 5, pp. 1715-1742. 
IASB (2009), International Financial Reporting Standard for Small and Medium-Sized Entities (IFRS for SMEs), Basis for Conclusions, International Accounting Standards Board, London.

ICAEW (2015), Press Release: EU Accounting Directive will have Profound Effect on Small Companies, Institute of Chartered Accountants in England \& Wales, London, available at: www.icaew.com/ en/about-icaew/newsroom/press-releases/2015-press-releases/icaew-eu-accounting-directivewill-have-profound-effect-on-small-companies (accessed 15 September 2015).

Khalil, M. and Simon, J. (2014), "Efficient contracting, earnings smoothing and managerial accounting discretion", Journal of Applied Accounting Research, Vol. 15 No. 1, pp. 100-122.

Kim, J., Li, L., Lu, L. and Yu, Y. (2016), "Financial statement comparability and expected crash risk", Journal of Accounting and Economics, Vol. 61 No. 2, pp. 294-312.

Kvaal, E. and Nobes, C. (2012), "IFRS policy changes and the continuation of national patterns of IFRS practice”, European Accounting Review, Vol. 21 No. 2, pp. 343-371.

Lang, M., Raedy, J.S. and Yetman, M.H. (2003), "How representative are firms that are cross-listed in the United States? An analysis of accounting quality", Journal of Accounting Research, Vol. 41 No. 2, pp. 363-386.

Li, K. and Sloan, R. (2015), "Has goodwill accounting gone bad?", Review of Accounting Studies, Vol. 22 No. 2, pp. 964-1003.

McInnis, J. (2010), "Earnings smoothness, average returns, and implied cost of equity capital", The Accounting Review, Vol. 85 No. 1, pp. 315-341.

ONS (2014), Preliminary Estimate of GDP-Time Series Dataset Q1 2014, Office for National Statistics, available at: www.ons.gov.uk/ons/rel/gva/gross-domestic-product-preliminary-estimate/q1-20 14/index.html (accessed 20 March 2016).

Ramanna, K. and Watts, R. (2012), "Evidence on the use of unverifiable estimates in required goodwill impairment", Review of Accounting Studies, Vol. 17 No. 4, pp. 749-780.

Schipper, K. (2007), "Required disclosures in financial reports", The Accounting Review, Vol. 82 No. 2, pp. 301-326.

Soderstrom, N. and Sun, K. (2007), "IFRS adoption and accounting quality: a review", European Accounting Review, Vol. 16 No. 4, pp. 675-702.

Szczesny, A. and Valentincic, A. (2013), "Write-offs in private firms - the case of German SMEs", Journal of Business Finance \& Accounting, Vol. 40 Nos 3-4, pp. 285-317.

vanTendeloo, B. and Vanstraelen, A. (2008), "Earnings management and audit quality in Europe: evidence from the private client segment market”, European Accounting Review, Vol. 17 No. 3, pp. 447-469.

\section{Further reading}

DeFond, M., Hung, M., Li, S. and Li, Y. (2015), "Does mandatory IFRS adoption affect crash risk?”, Accounting Review, Vol. 90 No. 1, pp. 265-299.

Lang, M., Raedy, J.S. and Wilson, W. (2006), "Earnings management and cross listing: are reconciled earnings comparable to US earnings?", Journal of Accounting and Economics, Vol. 42 No. 1, pp. 255-283.

\section{Corresponding author}

Siming Liu can be contacted at: Siming.Liu@brunel.ac.uk

For instructions on how to order reprints of this article, please visit our website:

www.emeraldgrouppublishing.com/licensing/reprints.htm

Or contact us for further details: permissions@emeraldinsight.com 